\title{
Midazolam attenuates ketamine-induced abnormal perception and thought process but not mood changes
}

\author{
Manzo Suzuki MD, * \\ Kentaro Tsueda MD, * \\ Peter S. Lansing $\mathrm{MD}^{*}$ \\ Merritt M. Tolan MD, * \\ Thomas M. Fuhrman MD, * \\ Rachel A. Sheppard BS, * \\ Harrell E. Hurst PhD, $\dagger$ \\ Steven B. Lippmann MD‡
}

Purpose: To determine the effects of midazolam, $30 \mathrm{ng} \cdot \mathrm{mL}^{-1}$, on altered perception, mood, and cognition induced by ketamine.

Methods: After ketamine was administered to achieve target concentrations of 50,100 , or $150 \mathrm{ng} \cdot \mathrm{mL}^{-1}$ in I I volunteers, perception, mood, and thought process were assessed by a visual analog scale. Mini-Mental State examination (MMSE) assessed cognition. Boluses of midazolam, 30, I4.5, and $12 \mu \mathrm{g} \cdot \mathrm{kg}^{-1}$, were injected every 30 min to maintain the plasma concentration at $30 \mathrm{ng} \cdot \mathrm{mL}^{-1}$, which was reached $30 \mathrm{~min}$ after each injection.

Results: Ketamine produced changes in perception about the body $(P<0.01,0.001$, and 0.0001 at 30, 60, and $90 \mathrm{~min})$, surroundings $(P<0.0 \mathrm{I}$ and $0.000 \mathrm{I}$ at 60 and $90 \mathrm{~min})$, time $(P<0.002$ and $0.000 \mathrm{I}$ at 60 and $90 \mathrm{~min})$, reality $(P<0.001$ and 0.0001 at 60 and $90 \mathrm{~min})$, sounds $(P<0.002$ at $90 \mathrm{~min})$, and meaning $(P<0.05$ at 90 $\mathrm{min})$. Subjects felt less energetic and clearheaded $(P<0.02$ and 0.05$)$ during ketamine, midazolam, and their coadministration. Ketamine impaired thought process $(P<0.003$ and 0.0001 at 60 and 90 min). Ketamine and midazolam decreased mean total MMSE and recall scores $(P<0.001$ for both). Co-administration reduced the number of subjects with perceptual (body, $P<0.01$ and 0.001 at 30 and $60 \mathrm{~min}$ ) and thought process abnormalities. Within the range of observation, co-administration did not affect the changes in mood or recall.

Conclusion: Midazolam attenuates ketamine-induced changes in perception and thought process.

Objectif : Déterminer les effets de $30 \mathrm{ng} \cdot \mathrm{mL}^{-1}$ de midazolam sur les changements de perception, d'humeur et de fonction cognitive induits par la kétamine.

Méthode : Après l'administration de kétamine visant à obtenir des concentrations cibles de 50, I00, ou I50 $\mathrm{ng} \cdot \mathrm{mL}^{-1}$ chez I I volontaires, la perception, l'humeur et la fonction cognitive ont été évaluées à l'aide d'une échelle visuelle analogique. L'examen MMS de Folstein et coll. (MMS) a servi à évaluer la fonction cognitive. Des bolus de midazolam de $30,14,5$ et $12 \mu \mathrm{g} \cdot \mathrm{kg}^{-1}$ ont été injectés à toutes les 30 min afin de maintenir la concentration plasmatique à $30 \mathrm{ng} \cdot \mathrm{mL}^{-1}$, concentration atteinte 30 min après chaque injection.

Résultats : La kétamine a modifié la perception du corps $(P<0,0$ I; 0,00I et 0,000 Ì 30, 60 et $90 \mathrm{~min})$, de l'environnement $(P<0,0$ I et 0,000 I à 60 et $90 \mathrm{~min})$, du temps $(P<0,002$ et 0,000 I à 60 et $90 \mathrm{~min})$, de la réalité $(P<0,00$ I et 0,000 I à 60 et $90 \mathrm{~min})$, des sons $(P<0,002$ à $90 \mathrm{~min})$ et du sens $(P<0,05$ à $90 \mathrm{~min})$. Les sujets se sentaient moins énergiques et moins lucides $(P<0,02$ et 0,05$)$ pendant l'administration de kétamine, de midazolam et pendant leur co-administration. La kétamine a altéré le processus cognitif $(P<0,003$ et 0,000 I à 60 et $90 \mathrm{~min}$ ). La kétamine et le midazolam ont fait baisser les scores totaux moyens de MMS et de mémoire $(P<0,00$ I pour les deux). La co-administration a réduit le nombre de sujets dont les perceptions (corps, $P<0,0$ I et 0,00 I à 30 et $60 \mathrm{~min}$ ) et la fonction cognitive étaient modifiées. Pendant le temps d'observation, la co-administration n'a pas eu d'effet sur les changements d'humeur ou de mémoire.

Conclusion : Le midazolam diminue les changements de perception et de cognition induits par la kétamine.

From the Departments of Anesthesiology, ${ }^{*}$ Pharmacology and Toxicology, $†$ and Psychiatry, $\ddagger$ University of Louisville School of Medicine, Louisville, KY, USA.

Address correspondence to: Kentaro Tsueda MD, Department of Anesthesiology, University of Louisville, Louisville, KY 40292 , USA.

Phone: 502-852-5851; Fax: 502-852-6056; E-mail: rashep01@gwise.louisville.edu Accepted for Publication June 15, 2000. 


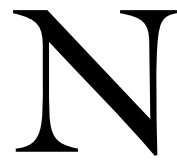

- METHYL-D-ASPARTATE (NMDA) receptors are located predominantly in the cortex, basal ganglia, and the structures associated with sensory systems and are important in corticofugal and corticocortical interaction. ${ }^{1}$ It has been suggested that NMDA-receptor mediated synaptic potentiation may be an essential process involved in memory and learning ${ }^{1}$ as well as the development of sensory systems. ${ }^{2}$ Ketamine, an NMDA receptor antagonist, activates the thalamic and limbic systems with concomitant depression of thalamo-neocortical pathways, ${ }^{3}$ and increases cerebral oxygen consumption $^{4}$ and hippocampal glucose utilization. ${ }^{5}$ At anesthetic doses ( $\left.1-3 \mathrm{mg} \cdot \mathrm{kg}^{-1}\right)$, ketamine may produce unpleasant dreams or psychotomimetic symptoms in more than one-third of patients on emergence from anesthesia. ${ }^{6}$ At subanesthetic doses $\left(100-500 \mu \mathrm{g} \cdot \mathrm{kg}^{-1}\right)$, ketamine impairs some domains of cognition (vigilance and memory), ${ }^{2,7,8}$ alters mood states, ${ }^{7-9}$ and produces a dose-related impairment of sensory perception or sensory integration in healthy human volunteers. ${ }^{7-9}$ Perceptual and mood changes at higher ranges of analgesic doses (e.g., $500 \mu \mathrm{g} \cdot \mathrm{kg}^{-1}$ ) are shown to resemble some aspects of psychosis, as in schizophrenia, and are associated with dysphoria. ${ }^{7}$

Recently, low-dose ketamine has been used together with midazolam, a competitive agonist for the subreceptor of the $\gamma$-aminobutyric acid $\left(\mathrm{GABA}_{\mathrm{A}}\right)$ receptor, and an opioid for sedation and analgesia during monitored anesthesia care. Benzodiazepines are reported to reduce psychotomimetic manifestations during the emergence from ketamine anesthesia. ${ }^{6}$ However, it is not clear whether benzodiazepines attenuate changes in perception, mood, and amnesia or affect the level of sedation induced by low-dose ketamine. We studied the effects of midazolam on the changes in perception, mood, and cognition, as well as on the sedation produced by low-dose ketamine.

Materials and Methods

Eleven male volunteers were recruited for this randomized, double-blind, cross-over study. Age ranged from 27 to $45 \mathrm{yr}$. Body weight was $91 \pm 14(\mathrm{SD}) \mathrm{kg}$ and height was $180 \pm 7 \mathrm{~cm}$. None of the subjects had psychiatric diseases, psychological problems, systemic illness, drug dependence, or used medicines that affect the central nervous system. Institutionally approved, written informed consent was obtained from each subject. All subjects had four sessions, each at least one week apart, in which perception, mood, and $\operatorname{cog}$ nition were evaluated: 1) while receiving normal saline; 2) at plasma ketamine target concentrations of 50,100 , and $\left.150 \mathrm{ng} \cdot \mathrm{mL}^{-1} ; 3\right)$ at a plasma midazolam concentration of approximately $30 \mathrm{ng} \cdot \mathrm{mL}^{-1}$; and 4) during co-administration of ketamine at target concentrations and the midazolam target concentration, $30 \mathrm{ng} \cdot \mathrm{mL}^{-1}$. Each subject was randomly assigned, according to a computer generated schedule, to a different order in which drug regimens were studied. One of the investigators, who did not participate in the assessment of patients, prepared $10 \mathrm{~mL}$ syringes containing normal saline or normal saline with midazolam, and a $30 \mathrm{~mL}$ syringe containing normal saline with or without ketamine $0.25 \%$.

To obtain target plasma concentrations, ketamine at a concentration of $2,500 \mu \mathrm{g} \cdot \mathrm{mL}^{-1}$ was infused using a Harvard pump 22 ${ }^{\text {TM }}$ (Harvard Apparatus, Holliston, MA) controlled by the Stanpump program (Steven L. Shafer, M.D., Department of Anesthesiology, Stanford University) based on pharmacokinetic data. ${ }^{10}$ Three target concentrations were maintained for $30 \mathrm{~min}$ at each level. Four boluses of midazolam, 30, 14.5, and $12 \mu \mathrm{g} \cdot \mathrm{kg}^{-1}$, were injected every $30 \mathrm{~min}$, to attain a plasma concentration of $30 \mathrm{ng} \cdot \mathrm{mL}^{-1}, 30 \mathrm{~min}$ after each injection. ${ }^{1}{ }^{1}$

Perceptual change was assessed using a visual ana$\log$ scale (VAS) in eight categories (i.e., body, surroundings, time, reality, colours, sound, voices [e.g., I hear voices that are unreal], and meaning [e.g., events, objects, and people have particular meaning for me]). ${ }^{9}$ The VAS was anchored by "not at all" at one end and "extremely" at the other. Mood was assessed using a similarly scaled VAS in 6 subsets of mood states (anxious-composed, hostile-agreeable, depressed-elated, unsure-confident, tired-energetic, and confused-clearheaded). ${ }^{9}$ Cognition was evaluated using the MiniMental State Examination (MMSE, 0 - 30), ${ }^{12}$ which assessed five areas of cognitive function (i.e., orientation $[0-10]$, registration $[0-3]$, recall $[0-3$, attention $[0-5]$, and language fluency [0 - 9]). Thought process and the content of thought were assessed using a similarly anchored VAS (i.e., I have difficulty in concentrating on a thought and/or have flight of ideas). ${ }^{9}$ Paranoia was assessed using the VAS to measure suspicion (i.e., I had suspicious ideas or beliefs that others were against me). ${ }^{9}$

Sedation was assessed by the Observer's Assessment of Alertness/Sedation $(\mathrm{OAA} / \mathrm{S})$ score: $5=$ responds readily to name spoken in normal tone; $4=$ lethargic response to name spoken in normal tone; 3 = responds after name is called loudly and/or repeatedly; $2=$ responds after mild prodding or shaking; and $\mathrm{l}=$ does not respond to mild shaking. ${ }^{13}$ Subjective sense of drowsiness was assessed by a VAS in which the worst drowsiness was defined as when subjects could barely keep their eyes open., ${ }^{2,9}$

Plasma ketamine and midazolam concentrations 
TABLE I Blood pressure $(\mathrm{BP})$ and heart rate $($ mean \pm SD) during placebo, ketamine, midazolam, and coadministration $(\mathrm{n}=11)$

\begin{tabular}{llllll}
\hline & & & Time (min) & \\
& & 0 & $30^{*}$ & $60+$ & $90 \neq$ \\
\hline Systolic BP (mmHg) & Midazolam & $126 \pm 16$ & $114 \pm 15$ & $113 \pm 15$ & $116 \pm 14$ \\
& Ketamine & $131 \pm 12$ & $129 \pm 14$ & $130 \pm 10$ & $135 \pm 16$ \\
& Co-admin & $128 \pm 16$ & $120 \pm 13$ & $121 \pm 19$ & $124 \pm 16$ \\
& Placebo & $125 \pm 11$ & $119 \pm 13$ & $119 \pm 8$ & $123 \pm 8$ \\
Diastolic BP (mmHg) & Midazolam & $65 \pm 13$ & $59 \pm 10$ & $60 \pm 10$ & $62 \pm 11$ \\
& Ketamine & $72 \pm 7$ & $68 \pm 8$ & $74 \pm 8$ & $76 \pm 11$ \\
& Co-admin & $69 \pm 11$ & $56 \pm 8$ & $64 \pm 13$ & $66 \pm 12$ \\
Heart rate $(\mathrm{bpm})$ & Placebo & $64 \pm 5$ & $62 \pm 9$ & $62 \pm 8$ & $65 \pm 6$ \\
& Midazolam & $67 \pm 11$ & $63 \pm 12$ & $61 \pm 9$ & $58 \pm 11$ \\
& Ketamine & $72 \pm 12$ & $68 \pm 11$ & $67 \pm 9$ & $71 \pm 11$ \\
& Co-admin & $71 \pm 14$ & $68 \pm 10$ & $71 \pm 11$ & $73 \pm 13$ \\
\hline
\end{tabular}

${ }^{\mathrm{a}} P=0.0001 .{ }^{\mathrm{b}} P=0.001$.

*ketamine, $45 \pm 15(\mathrm{SD}) \mathrm{ng} \cdot \mathrm{mL}^{-1}$; midazolam, $32 \pm 6 \mathrm{ng} \cdot \mathrm{mL}^{-1}$; and ketamine, $59 \pm 13 \mathrm{ng} \cdot \mathrm{mL}^{-1}$ and midazolam, $32 \pm 7 \mathrm{ng} \cdot \mathrm{mL}-1 \mathrm{during}$ coadministration. †ketamine, $93 \pm 29 \mathrm{ng} \cdot \mathrm{mL}^{-1}$; midazolam, $29 \pm 11 \mathrm{ng} \cdot \mathrm{mL}^{-1}$; and ketamine, $103 \pm 25 \mathrm{ng} \cdot \mathrm{mL}^{-1}$ and midazolam, $35 \pm 9$ $\mathrm{ng} \cdot \mathrm{mL}^{-1}$ during coadministration. łketamine, $146 \pm 34 \mathrm{ng} \cdot \mathrm{mL}^{-1}$, midazolam, $29 \pm 12 \mathrm{ng} \cdot \mathrm{mL}^{-1}$, and ketamine, $158 \pm 35 \mathrm{ng} \cdot \mathrm{mL}^{-1} \mathrm{and}$ midazolam, $32 \pm 11 \mathrm{ng} \cdot \mathrm{mL}^{-1}$ during coadministration.

were measured using capillary gas chromatography with nitrogen-selective detection by adapting previously published methods for ketamine ${ }^{14}$ and midazolam. ${ }^{15}$ Phencyclidine and flurazepam, respectively, were used as internal standards. Limits of detection for both drugs were $1 \mathrm{ng} \cdot \mathrm{mL}^{-1}$. Limits for quantification were set at $10 \mathrm{ng} \cdot \mathrm{mL}^{-1}$; at this low concentration the assay exhibited coefficients of variation of 4 and 12\% for the drugs, respectively.

In a quiet isolation room, an antecubital vein was cannulated for infusion in an arm in the first four patients. Both antecubital veins were cannulated for infusion and blood samples in the last seven subjects. After a rest for 20 to $30 \mathrm{~min}$, baseline data were obtained on perception, mood states, cognition, paranoia, and sedation. According to the assignment, subjects received a $10 \mathrm{ml}$ bolus injection over $20 \mathrm{sec}$ of normal saline with or without $30 \mu \mathrm{g} \cdot \mathrm{kg}^{-1}$ midazolam, and infusion of normal saline or ketamine $0.25 \%$ to attain a plasma concentration of $50 \mathrm{ng} \cdot \mathrm{mL}^{-1}$. A bolus of normal saline or midazolam, 14.5 and $12.0 \mu \mathrm{g} \cdot \mathrm{kg}^{-1}$, was repeated every $30 \mathrm{~min}$. Ketamine infusion rate was increased step-wise every $30 \mathrm{~min}$ to attain target plasma concentrations of 100 and $150 \mathrm{ng} \cdot \mathrm{mL}^{-1}$. Assessments of perception, mood, cognition, paranoia, and sedation were repeated 24 min after each injection. A blood sample was obtained after each assessment. A measure of electroencephalogram (EEG) (i.e., bispectral index [BIS]) was monitored using Aspect A-1000 EEG Brain Monitoring System $^{\text {TM }}$ (Aspect Medical Systems, Natick, MA) with the system bandpass set at $1 \mathrm{~Hz}$ and $30 \mathrm{~Hz}$ and the electrode impedance kept below $5 \mathrm{kOhm}($ at $12 \mathrm{~Hz}$ ). Electrocardiogram and arterial oxygen saturation were monitored. Non-invasive blood pressure (BP, mm $\mathrm{Hg})$, heart rate (HR, bpm), and respiratory rate (RR, $/ \mathrm{min}$ ) were recorded every five minutes. Dysphoria was to be treated by 1-2 mg midazolam, i.v.

Differences among groups in VAS scores for mood states, subjective sense of drowsiness, MMSE scores, $\mathrm{OAA} / \mathrm{S}$ scores, vital signs, and EEG measures (mean values of 60 epochs) were tested by two-way within subjects, multivariate, repeated measures analysis of variance using baseline values as a covariate. Where applicable, the data were further analyzed using the Sidak multiple comparison method. ${ }^{16}$ Mood and BIS scores were further tested for trend over time using the SAS-PROC-MIXED (repeated measures) test. VAS values measuring perception, thought process, and suspicion were dichotomized into scores of zero (non-responder) and one (responder). The dichotomized values were analyzed using Cochran's $Q$ statistics at 30,60 , and 90 min. $P<0.05$ was considered to be statistically significant.

\section{Results}

There was a small increase in systolic and diastolic BP during ketamine infusion $(P<0.0001$ and $P<0.001)$ (Table I). There was no change in HR during ketamine infusion. Midazolam reduced HR $(P<0.05)$, but produced no change in BP. There were no changes in BP or HR during co-administration. There was no group difference in RR.

Plasma concentrations of ketamine during ketamine infusion were $45 \pm 15($ mean $\pm S D), 93.0 \pm 29$, 
TABLE II Differences ( $P$ values by Cochran $Q$ test) in the number of subjects having perceptual changes between 4 treatment regimes (i.e., placebo, ketamine, midazolam, and coadministration at 30,60 , and $90 \mathrm{~min}$ assessment $)(\mathrm{n}=11)$

\begin{tabular}{llll}
\hline Perception & $30^{*}$ & $\begin{array}{c}\text { Time (min) } \\
60 \dagger\end{array}$ & $90 \neq$ \\
\hline Body & 0.007 & 0.001 & 0.0001 \\
Surrounding & NS & 0.008 & 0.0001 \\
Time & NS & 0.002 & 0.0001 \\
Reality & NS & 0.001 & 0.0001 \\
Color & NS & NS & NS \\
Sound & NS & NS & 0.002 \\
Voice & NS & NS & NS \\
Meaning & NS & NS & 0.029 \\
\hline
\end{tabular}

*ketamine, $45 \pm 15(\mathrm{SD}) \mathrm{ng} \cdot \mathrm{mL}^{-1}$; midazolam, $32 \pm 6 \mathrm{ng} \cdot \mathrm{mL}^{-1}$; and ketamine, $59 \pm 13 \mathrm{ng} \cdot \mathrm{mL}^{-1}$ and midazolam, $32 \pm 7 \mathrm{ng} \cdot \mathrm{mL}^{-1}$ during coadministration. †ketamine, $93 \pm 29 \mathrm{ng} \cdot \mathrm{mL}^{-1}$; midazolam, $29 \pm 11 \mathrm{ng} \cdot \mathrm{mL}^{-1}$; and ketamine, $103 \pm 25 \mathrm{ng} \cdot \mathrm{mL}^{-1}$ and midazolam, $35 \pm 9 \mathrm{ng} \cdot \mathrm{mL}^{-1}$ during coadministration. łketamine, $146 \pm 34 \mathrm{ng} \cdot \mathrm{mL}^{-1}$; midazolam, $29 \pm 12 \mathrm{ng} \cdot \mathrm{mL}^{-1}$; and ketamine, $158 \pm 35 \mathrm{ng} \cdot \mathrm{mL}^{-1}$ and midazolam, $32 \pm 11 \mathrm{ng} \cdot \mathrm{mL}^{-1}$ during coadministration.

and $146 \pm 34 \mathrm{ng} \cdot \mathrm{mL}^{-1}$ at 30,60 , and $90 \mathrm{~min}$, respectively. Plasma midazolam concentrations during midazolam administration were $32 \pm 6,29 \pm 11$, and $29 \pm$ $12 \mathrm{ng} \cdot \mathrm{mL}^{-1}$ at 30,60 , and $90 \mathrm{~min}$. During the coadministration, ketamine concentrations were $59 \pm 13$, $103 \pm 25$, and $158 \pm 35 \mathrm{ng} \cdot \mathrm{mL}^{-1}$, and midazolam concentrations were $32 \pm 7,35 \pm 9$, and $32 \pm 11 \mathrm{ng} \cdot \mathrm{mL}^{-1}$ at 30,60 , and $90 \mathrm{~min}$, respectively.

There were differences among the drug regimens in the number of subjects having perceptual abnormality in six out of eight categories (i.e., body, surrounding, time, reality, sound, and meaning) (Table II). More subjects experienced the abnormality at higher plasma ketamine concentrations. They felt heavy, light, moving, floating and/or undulating, and stated that the entire or a part of the body was tingling, or that a part of the body was out of proportion in size, displaced or absent. One subject thought his right hand was his left hand and vice versa. Two subjects felt their body was so heavy that they were unable to lift a hand. Perceptions of surroundings were described as spinning, in slow motion, smaller in appearance, or that the surroundings appeared as if on a scroll. Time was felt to pass faster or slower, or to have stopped. The subjects described colour as brighter, less bright, or blending. Sound was described as far away, louder, clearer, or amplified. Our subjects felt "weird," "strange," and/or "detached," and some felt that the reality was a slow-motion dream. Two subjects thought they were dreaming of riding a comet and a spaceship. Neither placebo nor midazolam

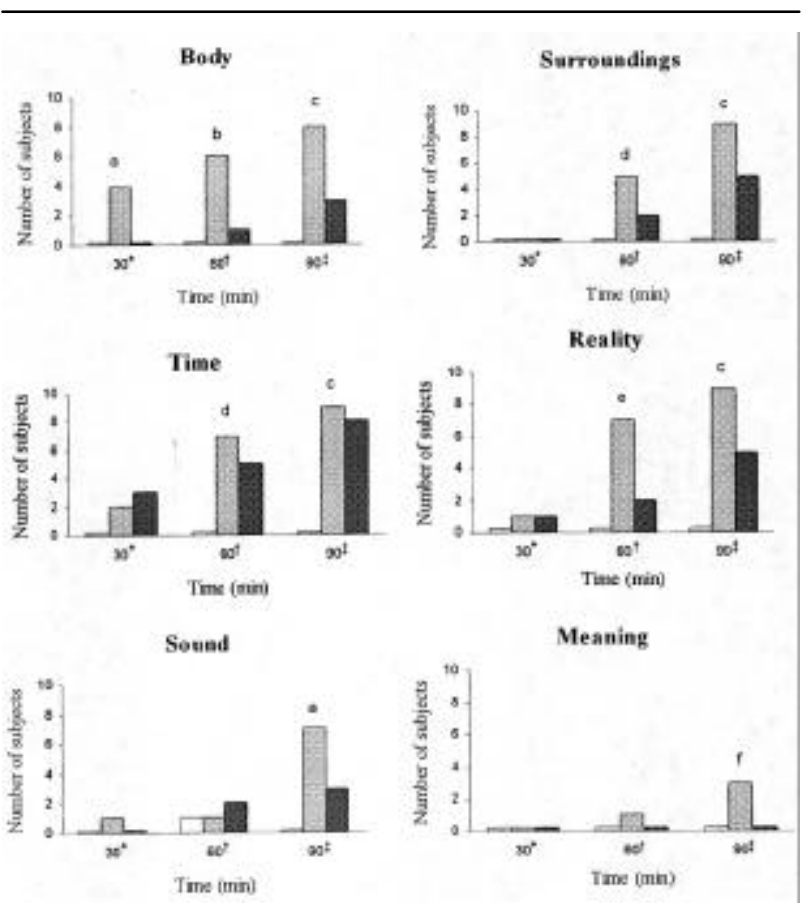

FIGURE 1 the number of subjects having perceptual abnormality. = midazolam administration, $\square=$ ketamine infusion, and

$=$ coadministration. ${ }^{\mathrm{a}} P<0.01$ and ${ }^{\mathrm{b}} P=0.001$ vs placebo, midazolam, and coadministration. ${ }^{c} P=0.0001,{ }^{\mathrm{d}} P<0.01$, and $\mathrm{e} P=$ 0.01 vs placebo and midazolam. ${ }^{\mathrm{f}} P<0.05$ vs placebo, midazolam, and coadministration.

*ketamine, $45 \pm 15(\mathrm{SD}) \mathrm{ng} \cdot \mathrm{mL}^{-1}$; midazolam, $32 \pm 6 \mathrm{ng} \cdot \mathrm{mL}^{-1}$; ketamine, $59 \pm 13 \mathrm{ng} \cdot \mathrm{mL}^{-1}$ and midazolam, $32 \pm 7 \mathrm{ng} \cdot \mathrm{mL}^{-1}$ during coadministration. †ketamine, $93 \pm 29 \mathrm{ng} \cdot \mathrm{mL}^{-1 ;}$ midazolam, $29 \pm$ $11 \mathrm{ng} \cdot \mathrm{mL}^{-1}$; and ketamine, $103 \pm 25 \mathrm{ng} \cdot \mathrm{mL}^{-1}$ and midazolam, 35 $\pm 9 \mathrm{ng} \cdot \mathrm{mL}^{-1}$ during coadministration. $\ddagger$ ketamine, $146 \pm 34$ $\mathrm{ng} \cdot \mathrm{mL}^{-1}$; midazolam, $29 \pm 12 \mathrm{ng} \cdot \mathrm{mL}^{-1}$; and ketamine, $158 \pm 35$ $\mathrm{ng} \cdot \mathrm{mL}^{-1}$ and midazolam, $32 \pm 11 \mathrm{ng} \cdot \mathrm{mL}^{-1}$ during coadministration.

produced perceptual change, except for one subject receiving midazolam who felt sounds were unusually loud. Coadministration of midazolam attenuated the ketamine-induced change in body perception $(P<0.01$ and 0.001 at higher ketamine target concentrations). Although differences were not statistically significant in the other five categories, the numbers of subjects with perceptual changes were lower during the coadministration than they were during the infusion of ketamine alone (Figure 1). None had dysphoria, hallucinations, or psychotic symptoms.

The VAS score during ketamine infusion was lower in two subsets of mood states (i.e., tired-energetic $[P$ $<0.02]$, and confused-clearheaded $[\mathrm{P}<0.05])$. The SAS-PROC-MIXED (repeated measures) test showed 
TABLE III The total Mini-Mental State Examination (MMSE) score (mean \pm SD) and the scores for five domains (i.e., orientation, registration, recall, attention, and language fluency) during placebo, ketamine, midazolam, and coadministration $(\mathrm{n}=1 \mathrm{l})$

\begin{tabular}{lllll}
\hline & Placebo & Ketamine & Midazolam & Co-administration \\
\hline Orientation & $10.00 \pm 0.00$ & $10.00 \pm 0.00$ & $10.00 \pm 0.00$ & $9.98 \pm 0.02$ \\
Registration & $3.00 \pm 0.00$ & $3.00 \pm 0.00$ & $3.00 \pm 0.00$ & $3.00 \pm 0.00$ \\
Recall & $2.93 \pm 0.03^{\mathrm{b}}$ & $2.44 \pm 0.14^{\mathrm{a}}$ & $1.93 \pm 0.22^{\mathrm{a}}$ & $1.86 \pm 0.25^{\mathrm{a}}$ \\
Attention & $5.00 \pm 0.00$ & $5.00 \pm 0.00$ & $4.98 \pm 0.02$ & $4.89 \pm 0.05$ \\
Language & $9.00 \pm 0.00$ & $9.00 \pm 0.00$ & $9.00 \pm 0.00$ & $8.96 \pm 0.02$ \\
Total MMS score & $29.93 \pm 0.03^{\mathrm{b}}$ & $29.44 \pm 0.14^{\mathrm{a}}$ & $28.92 \pm 0.23^{\mathrm{a}}$ & $28.61 \pm 0.30^{\mathrm{a}}$ \\
\hline
\end{tabular}

${ }^{a} P<0.01$ vs placebo.

TABLE IV OAA/S scores, Drowsiness VAS scores, and BIS values (mean \pm SD) during placebo, ketamine, midazolamm, and coadministration $(\mathrm{n}=11)$

\begin{tabular}{llllll}
\hline & & \multicolumn{2}{c}{ Time (min) } & & $90 \neq$ \\
\hline OAA/S & & 0 & $30^{*}$ & $60+$ & $4.3 \pm 0.7$ \\
& Midazolam & $5.0 \pm 0.0$ & $4.4 \pm 0.9$ & $3.8 \pm 1.0$ & $3.9 \pm 0.3$ \\
& Ketamine & $5.0 \pm 0.0$ & $4.8 \pm 0.4$ & $4.5 \pm 0.5$ & $4.3 \pm 0.9$ \\
Coadmin & $5.0 \pm 0.0$ & $4.4 \pm 0.8$ & $4.0 \pm 1.2$ & $5.0 \pm 0.0$ \\
& Placebo & $5.0 \pm 0.0$ & $5.0 \pm 0.0$ & $5.0 \pm 0.0$ & $62 \pm 20$ \\
Browsiness & Midazolam & $0 \pm 0$ & $58 \pm 22$ & $64 \pm 20$ & $72 \pm 26$ \\
& Ketamine & $0 \pm 0$ & $36 \pm 23$ & $61 \pm 27$ & $74 \pm 22$ \\
& Coadmin & $0 \pm 0$ & $55 \pm 17$ & $62 \pm 23$ & $0 \pm 0$ \\
& Placebo & $0 \pm 0$ & $0 \pm 0$ & $0 \pm 0$ & $78 \pm 21$ \\
& Midazolam & $96 \pm 2$ & $81 \pm 19$ & $75 \pm 18$ & $97 \pm 1$ \\
& Ketamine & $97 \pm 1$ & $96 \pm 3$ & $97 \pm 1$ & $90 \pm 15$ \\
\hline
\end{tabular}

a $P=0.001$ vs the average scores for the midazolam, ketamine, and coadministration groups.

${ }^{\mathrm{b}} P=0.0001$ vs the average scores for the midazolam, ketamine, and coadministration groups.

${ }^{c} P=0.002$ vs the average scores for the midazolam and coadministration groups.

*ketamine, $45 \pm 15(\mathrm{SD}) \mathrm{ng} \cdot \mathrm{mL}^{-1}$; midazolam, $32 \pm 6 \mathrm{ng} \cdot \mathrm{mL}^{-1}$; and ketamine, $59 \pm 13 \mathrm{ng} \cdot \mathrm{mL}^{-1}$ and midazolam, $32 \pm 7 \mathrm{ng} \cdot \mathrm{mL}^{-1} \mathrm{during}$ coadministration. tketamine, $93 \pm 29 \mathrm{ng} \cdot \mathrm{mL}^{-1}$; midazolam, $29 \pm 11 \mathrm{ng} \cdot \mathrm{mL}^{-1}$; and ketamine, $103 \pm 25 \mathrm{ng} \cdot \mathrm{mL}^{-1}$ and midazolam, $35 \pm 9$ $\mathrm{ng} \cdot \mathrm{mL}^{-1}$ during coadministration. łketamine, $146 \pm 34 \mathrm{ng} \cdot \mathrm{mL}^{-1}$; midazolam, $29 \pm 12 \mathrm{ng} \cdot \mathrm{mL}^{-1}$; and ketamine, $158 \pm 35 \mathrm{ng} \cdot \mathrm{mL}^{-1} \mathrm{and}$ midazolam, $32 \pm 11 \mathrm{ng} \cdot \mathrm{mL}^{-1}$ during coadministration.

significant trends over time (i.e., plasma concentration $)\left(\operatorname{mood}\right.$ state $=\mathrm{A} \times$ time $[\mathrm{min}]+\mathrm{B} \times$ time $\left.^{2}\right)$. There were positive changes over plasma concentrations in three subsets (anxious-composed $[\mathrm{B}=0.002$, $P<0.02]$, depressed-elated $[\mathrm{B}=0.003, P<0.001]$, and hostile-agreeable $[\mathrm{B}=0.002, P<0.01])$, and negative changes in two subsets of mood states (tiredenergetic and confused-clearheaded) during ketamine infusion. The subjects described their mood as more positive, high, uplifted, and euphoric, and stated that they felt relaxed, although they were less energetic and increasingly less clearheaded. Midazolam produced a negative change over time in one subset (confusedclearheaded $[\mathrm{A}=-0.406, P<0.0002$ and $\mathrm{B}=0.0023$, $\mathrm{P}<0.009])$. The subjects expressed their mood as less energetic but relaxed. One subject felt lethargic.
During co-administration, there was a positive change over time in one subset (depressed-elated $[\mathrm{B}=0.002$, $P<0.05]$ ) and negative changes in two subsets (tiredenergetic and confused-clear-headed). Ten of 11 subjects stated that they felt good and relaxed. One said that he felt tired.

There was a difference in the mean total MMSE score $(P<0.01)$. The mean recall score was lower during administration of ketamine, midazolam, or coadministration than during the placebo run $(P<0.01)$ (Table III). There were no changes in the scores for registration, orientation, attention, and language fluency. The number of subjects having abnormal thought process increased, however, during ketamine infusion in a dose-dependent manner $(P<0.003$ and $P<0.0001$ at $60 \mathrm{~min}$ and $90 \mathrm{~min}$ assessment, respectively). The 


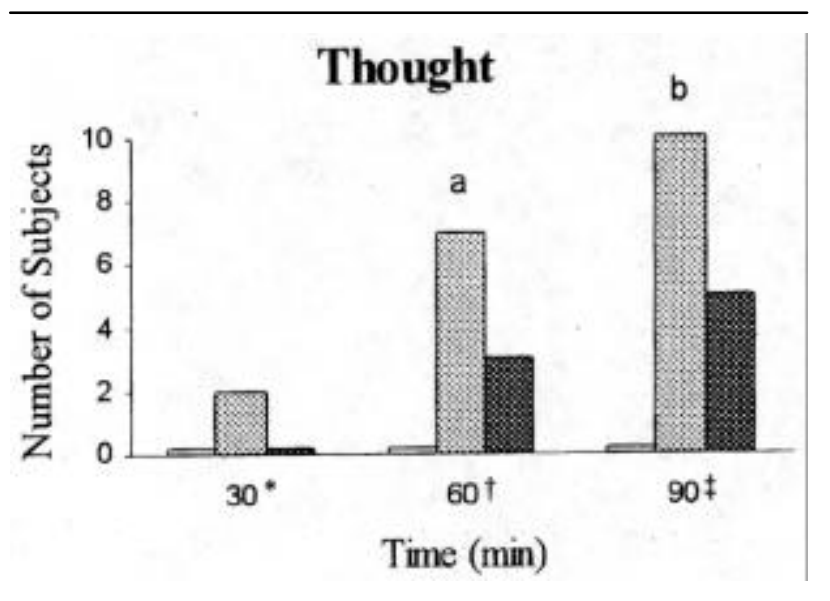

FIGURE 2 The number of subjects having abnormal thought processes. = midazolam administration, $\square=$ ketamine infusion, and $\square=$ coadministration. ${ }^{\mathrm{a}} P<0.01$ and ${ }^{\mathrm{b}} P=0.001$ vs placebo and midazolam.

*ketamine, $45 \pm 15(\mathrm{SD}) \mathrm{ng} \cdot \mathrm{mL}^{-1}$; midazolam, $32 \pm 6 \mathrm{ng} \cdot \mathrm{mL}^{-1}$; ketamine, $59 \pm 13 \mathrm{ng} \cdot \mathrm{mL}^{-1}$ and midazolam, $32 \pm 7 \mathrm{ng} \cdot \mathrm{mL}^{-1}$ during coadministration. †ketamine, $93 \pm 29 \mathrm{ng} \cdot \mathrm{mL}^{-1 ;}$ midazolam, $29 \pm$ $11 \mathrm{ng} \cdot \mathrm{mL}^{-1}$; and ketamine, $103 \pm 25 \mathrm{ng} \cdot \mathrm{mL}^{-1}$ and midazolam, 35 $\pm 9 \mathrm{ng} \cdot \mathrm{mL}^{-1}$ during coadministration. $\ddagger$ ketamine, $146 \pm 34$ $\mathrm{ng} \cdot \mathrm{mL}^{-1}$; midazolam, $29 \pm 12 \mathrm{ng} \cdot \mathrm{mL}^{-1}$; and ketamine, $158 \pm 35$ $\mathrm{ng} \cdot \mathrm{mL}^{-1}$ and midazolam, $32 \pm 11 \mathrm{ng} \cdot \mathrm{mL}^{-1}$ during coadministration.

subjects described their thoughts as "flight of ideas," "my thoughts are faster, busy, racing, or jumping," or "scenes from movies or past events keep popping into my head." Two subjects stated their thoughts slowed down transiently. Neither placebo nor midazolam produced a thought disorder. Co-administration reduced the number of subjects having ketamine-induced changes in thought process by $50 \%$ (Figure 2 ). Those who continued to have abnormal thought processes described their thoughts as floating, fleeting, blending, or finding it difficult to concentrate. Neither midazolam, ketamine, nor the co-administration produced changes in the suspicion (i.e., paranoia) score.

There was a difference in the average score of BIS over time $(P<0.02)$ and among the drug regimens $(P$ $=0.002)$. The BIS did not change during placebo or ketamine infusion but was lower during midazolam administration. The BIS appeared to increase during coadministration as plasma ketamine concentration increased $($ constant $=96.3 ; \mathrm{B}=-0.439[P=0.0001]$; and $\mathrm{B}=0.0032[P=0.0001])$ (Table IV). There were differences over time and among the drug regimens in the average score of drowsiness VAS $(P=0.0001$ for both) and OAA $/ \mathrm{S}$ (time, $P=0.003$, and the averaged scores, $P=0.001)$. The average drowsiness score during the placebo trial was lower and the average $\mathrm{OAA} / \mathrm{S}$ score was higher than those during the administration of midazolam and ketamine, as well as during co-administration.

\section{Discussion}

In this study, low-dose ketamine produced dose-related alterations in somesthetic and proprioceptive perceptions as well as auditory and visual perceptual changes, and positive relationships for subsets of mood states (i.e., elation, composure, and agreeableness), described as relaxed, better, uplifted, "high," and/or euphoric. Midazolam did not produce perceptual alterations or similar mood changes. Co-administration of midazolam attenuated the perceptual alterations but did not affect the mood changes. Both ketamine and midazolam impaired post-distraction but not immediate recall. Midazolam did not increase ketamine-induced memory impairment significantly. Ketamine induced a thought disorder. Midazolam attenuated the thought process abnormality. Ketamine, midazolam, and their coadministration all produced similar levels of sedation and drowsiness.

Dose-related perceptual alterations observed during ketamine infusion were not quantitative but were all qualitative. A sensation that a part of the body was missing, displaced, or the inability to tell the left hand from the right in our subjects is consistent with tactile agnosia, which is associated with a lesion in the posterior parietal lobe. ${ }^{17}$ These alterations indicate that ketamine affected a large area of sensory association cortices in our subjects, and that perceptual impairment induced by low-dose ketamine may involve the process of sensory integration. ${ }^{7}$ It has been shown that ketamine produces electroencephalographic ictal activity of the neocortex, thalamus, and hippocampus, and markedly increases the evoked potentials of the sensorimotor and visual cortex of cats. ${ }^{3}$ Ketamine increases porcine cerebral oxygen consumption ${ }^{4}$ and hippocampal glucose metabolism in rats, ${ }^{5}$ and has been reported to induce seizure activity in patients with temporal lobe epilepsy. ${ }^{18}$ Midazolam antagonizes the increase in oxygen consumption ${ }^{4}$ and the seizure activity produced by ketamine. These findings as well as the midazolam-induced attenuation of perceptual alterations observed in our subjects appear to be consistent with the concept that NMDA receptors may modulate functions of cortical and subcortical structures in adults. ${ }^{2}$

The striatal complexes (i.e., dorsal and ventral striatum and pallidum) have been recognized as a powerful inhibitory structure on the thalamus and the ascending 
reticular formation. Stimulation of the glutamatergic corticostriatal projection inhibits the thalamus and reticular nuclei, leading to reducted sensory transmission to cerebral cortices as well as a reduced state of arousal, whereas dopamine exerts an inhibitory influence on the striatal neurons, thus counteracting the inhibitory influence of the striatal complexes on the thalamus and the reticular formation. ${ }^{19,20}$ When the sensory transmission becomes excessive (e.g., the NMDA-receptor antagonist), the integral capacity of the cortex may break down, and confusion or psychosis may ensue. Reduction in dopaminergic $\left(\mathrm{D}_{2}\right)$ function (e.g., the $\mathrm{D}_{2}$-receptor antagonist) results in inhibition of motor and mental activity. Recent studies have also shown antagonistic interactions between the NMDAreceptor and the serotonergic, as well as noradrenergic and muscarinic activities. ${ }^{20}$

Subanesthetic doses of ketamine and its enantiomers have been shown to produce a feeling of "high" and to be anxiolytic at low doses, but anxiogenic at higher doses. ${ }^{2,7}$ The similarity in the "highs" produced by ketamine and alcohol intoxication has been attributed to the NMDA receptor antagonist property of both drugs. ${ }^{7}$ Our subjects described mood during ketamine infusion as "high,' while midazolam did not produce a state of "high," and the co-administration did not affect ketamine-induced positive mood, suggesting that ketamine and midazolam involve different mechanisms for mood alteration. The mechanism for ketamine-induced mood alteration is not clear. It is possible that increased thalamic sensory output to cerebral cortices secondary to ketamineinduced blockade of the corticostriatal glutamatergic pathway ${ }^{19,20}$ and a possible interaction with the serotonergic system, may have contributed to the ketamine-induced mood alteration. ${ }^{20}$

It has been suggested that NMDA receptor-induced long-term synaptic potentiation in the hippocampus and subsequent protein synthesis may be the mechanism underlying the formation of short-term, intermediate-term, and long-term memory in vertebrates. ${ }^{2}$ Reports in humans have shown that ketamine impairs post-distraction and delayed word recall, $2,7,8,22$ but may ${ }^{2}$ or may not ${ }^{7,8}$ affect immediate recall. A 24-word task has shown impaired immediate recall but preserved recognition memory, suggesting that ketamine may impair retrieval of information. ${ }^{22}$ Although it was suggested that observed discrepancies on immediate recall may be due to the level of the challenge the tasks impose and also ketamine-induced attention deficit, ${ }^{7}$ a later study with a less challenging task failed to detect impaired retrieval. ${ }^{2}$ Further, a recent study showed that ketamine-induced memory impairment was not related to concomitant attentional and behavioural changes. ${ }^{8}$ Thus, ketamine appears to impair early phases of memory formation, relatively sparing encoding and short-term memory. A benzodiazepine, on the other hand, has been considered to impair consolidation of newly acquired information through reduction in long-term potential, mediated by its action on the $\mathrm{GABA}_{\mathrm{A}}$ receptor. ${ }^{23}$ In our subjects, the MMSE showed impairment in post-distraction recall during ketamine or midazolam administration. Although midazolam did not increase ketamineinduced amnesia, a recent study reported that lorazepam increased the amnestic effect of ketamine. ${ }^{24}$ The small number of subjects in our study may be a factor in the lack of a statistical significance.

Ketamine has been shown to induce frontal lobe dysfunction (i.e., executive cognitive function, verbal fluency, and vigilance) in volunteers. ${ }^{7}{ }^{8} \mathrm{~A}$ thought disorder observed in our subjects during ketamine infusion was consistent with flight of ideas, a form of disorganized thought, which occurs in hyperadrenergic states (e.g., stimulant overdose and sedative withdrawal), anxiety and agitation, as well as in psychotic and manic presentations, ${ }^{25}$ suggesting that the thought disorder in our subjects may have been a manifestation of excitatory phenomenon. Benzodiazepines are usually effective for the treatment of hyperadrenergic states, anxiety, and agitation. ${ }^{26}$ The thought disorder in our subjects was attenuated by midazolam. Of interest in this context was a recent study that showed amelioration of ketamine-induced impairments in executive cognitive functions by co-administration of haloperidol, a $\mathrm{D}_{2}$-receptor antagonist, suggesting the possibility that ketamineinduced frontal lobe symptoms and disorganized, hyperactive thought may, at least in part, involve the striatal system. ${ }^{27}$

The absence of additive effect on the level of sedation during the co-administration suggests that ketamine and midazolam induce sedation by different mechanisms. In our subjects, ketamine produced active thoughts and awake level BIS, while midazolaminduced sedation was associated with quiet thought and a decline in BIS, although the levels of sedation were similar. During the coadministration, the thought status and BIS were between those obtained during the administration of ketamine and midazolam alone. The mechanism by which ketamine induces sedation is not known. However, association of hyperactive thought process with sedation observed in our subjects and the observations that subjects were rather awake than sleepy while receiving subanesthetic doses of ketamine ${ }^{7}$ may be consistent with arousal and increase in the thalamocortical activity mediated by the striatal mechanism. ${ }^{17,18}$ 
Presynaptic inhibition of the GABA receptor ${ }^{2} 8$ may also be a possible contributor to the lack of increase in sedation during the coadministration.

Our results suggest that midazolam attenuates perceptual abnormalities and thought disorder induced by low-dose ketamine without changes in sedation or drowsiness. The results also suggest that midazolam may not affect ketamine-induced amnesia or changes in mood.

\section{Acknowledgments}

The authors gratefully acknowledge Hoffman-La Roche for a gift of analytical grade midazolam, which was used for standardization of the gas chromatographic assay. We thank Robert L. Vogel PhD for his help in statistical analysis and Hassan Shahab MD for editorial advice.

\section{References}

1 Cotman CW, Monaghan DT. Excitatory amino acid neurotransmission: NMDA receptors and Hebb-type synaptic plasticity. Ann Rev Neurosci 1988; 11: 61-80.

2 Oye I, Paulsen O, Maurset A Effects of ketamine on sensory perception: evidence for a role of $\mathrm{N}$-methylD-asparate receptors. J Pharmacol Exp Ther 1992; 260: 1209-13.

3 Kayama $\Upsilon$, Iwama K. The EEG, evoked potentials, and single unit activity during during ketamine anesthesia in cats. Anesthesiology 1972; 36: 316-28.

4 Âkeson J, Björkman S, Messeter K, Rosén I. Low-dose midazolam antagonizes cerebral metabolic stimulation by ketamine in the pig. Acta Anaesthesiol Scand 1993; 37: 525-31.

5 Oguchi K, Arakawa K, Nelson SR, Samson F. The influence of droperidol, diazepam, and physostigmine on ketamine-induced behavior and brain regional glucose utilization in rat. Anesthesiology 1982; 57: 353-8.

6 White PF, Way WL, Trevor AJ. Ketamine - its pharmacology and therapeutic uses. Anesthesiology 1982; 56: 119-36.

7 Krystal JH, Karper LP, Seibyl JP, et al. Subanesthetic effects of noncompetitive NMDA antagonist, ketamine, in humans. Psychotomimetic, perceptual, cognitive, and neuroendocrine responses. Arch Gen Psychiatr 1994; 51: 199-214.

8 Malhotra AK, Pinals DA, Weingartner $H$, et al. NMDA receptor function and human cognition: the effects of ketamine in healthy volunteers. Neuropsychopharmacology 1996; 14: 301-7.

9 Bowdle TA, Radant AD, Cowley DS, Kharasch ED, Strassman RJ, Roy-Byrne PP. Psychedelic effects of ketamine in healthy volunteers. Relationship to steady-state plasma concentrations. Anesthesiology 1998; 88: 82-8.
10 Domino EF, Domino EE, Smith RE, et al. Ketamine kinetics in unmedicated and diazepam-premedicated subjects. Clin Pharmacol Ther 1984; 36: 645-53.

11 Greenblatt DJ, Ehrenberg BL, Gunderman J, et al. Pharmacokinetic and electroencephalographic study of intravenous diazepam, midazolam, and placebo. Clin Pharmacol Ther 1989; 45: 356-65.

12 Folstein MF, Folstein SE, McHugh PR "Mini-mental state." A practical method for grading the cognitive state of patients for the clinician. J Psychiatr Res 1975; 12: 189-98.

13 Chernik DA, Gillings D, Laine $H$, et al. Validity and reliability of the observer's assessment of alertness/sedation scale: study with intravenous midazolam. J Clin Psychopharmacol 1990; 10: 244-51.

14 Stiller RL, Dayton PG, Perel JM, Hug CC Jr. Gas chromatographic analysis of ketamine and norketamine in plasma and urine: nitrogen-sensitive detection. J Chromatogr 1982; 232: 305-14.

15 Vasiliades J, Owens C. Determination of midazolam in serum by gas chromatography with a nitrogen-sensitive detector. J Chromatogr 1980; 182: 439-44.

16 Westfall PH, Young SS. Resampling-Based Multiple Testing. Examples and Methods for $p$-Value Adjustment. New York: John Wiley \& Sons Inc., 1993: 64-6.

17 Gilroy J, Meyer JS. Medical Neurology, 3rd ed. New York: MacMillan Publishing Co., Inc., 1979.

18 Ferrer-Allado T, Brechner VL, Dymond A, Cozen H, Crandall $P$. Ketamine-induced electroconvulsive phenomena in the human limbic and thalamic regions. Anesthesiology 1973; 38: 333-44.

19 Carlsson M, Carlsson A. Schizophrenia: a subcortical neurotransmitter imbalance syndrome? Schizophr Bull 1990; 16: 425-32.

20 Carlsson A, Hansson LO, Waters N, Carlsson ML. Neurotransmitter aberrations in schizophrenia: new perspectives and therapeutic implications. Life Sci 1997; 61: 75-94.

21 Rosenzweig MR, Leiman AL, Breedlove SM. Biological Psychology. An Introduction to Behavioral, Cognitive and Clinical Neuroscience, 2nd ed. Sunderland: Sinauer Associates, Inc., 1999.

22 Ghoneim MM, Hinrichs JV, Mewaldt SP, Petersen RC Ketamine: behavioral effects of subanesthetic doses. J Clin Psychopharmacol 1985; 5: 70-7.

23 Barbee JG. Memory, benzodiazepines, and anxiety: integration of theoretical and clinical perspectives. J Clin Psychiatr 1993; 54: 86-97.

24 Krystal JH, Karper LP, Bennett A, et al. Interactive effects of subanesthetic ketamine and subhypnotic lorazepam in humans. Psychopharmacology 1998; 135: 213-29. 
25 Gitlin MJ. Clinical manifestations of psychiatric disorders. In: Kaplan HI, Sadock BJ (Eds.). Comprehensive Textbook of Psychiatry, 6th ed. Baltimore: Williams \& Wilkins., 1995: 637-69.

26 Yudofsky SC, Silver JM, Hales RE. Treatment of agitation and aggressive disorders. In: Schatzberg AF, Nemeroff CB (Eds.). Textbook of Psychopharmacology, lst ed. Washington, D.C.: American Psychiatric Press, Inc., 1995: 735-51.

27 Krystal JH, D'Souza DC, Karper LP, et al. Interactive effects of subanesthetic ketamine and haloperidol in healthy humans. Psychopharmacology 1999; 145: 193-204.

28 Murugaiah KD, Hemmings HC Jr. Effects of intravenous general anesthetics on $[3 \mathrm{H}] \mathrm{GABA}$ release from rat cortical synaptosomes. Anesthesiology 1998; 89: 919-28. 